\title{
IJTIHAD JAMA'I NAHDATUL ULAMA (NU) DAN IJTIHAD QIYASI MUHAMMADIYAH TENTANG BUNGA BANK DALAM PRAKTIK PERBANKAN
}

\author{
Oleh: Rizal Bin Jami'an \\ Universitas Islam Negeri (UIN) Sunan Kalijaga Yogyakarta \\ Email: rizal_jamian@gmail.com
}

\begin{abstract}
Abstrak
Bunga bank perbankan di Indonesia masih tetap menjadi perdebatan di kalangan umat Islam dengan status hukum: haram mutlak, dapat dibenarkan, atau status hukum yang lain. Nahdatul Ulama (NU) dan Muhammadiyah sebagai 2 (dua) organisasi Islam terbesar di Indonesia berusaha memberikan status hukum bunga bank. Analisis dalam artikel ini difokuskan pada pola ijtihad yang dilakukan oleh kedua organisasi Islam tersebut. Hasil analisis menunjukkan bahwa NU melakukan ijtihad Jama'l dalam menetapkan hukum bunga bank dengan tetap menyandarkan pendapat ulama (Syafi'iyah). NU berpendapat bahwa bunga adalah riba baik sedikit atau banyak, ada kategori ad'afan muda'afah atau tidak. NU tidak membedakan bank yang dimiliki oleh Negara atau swasta. Bahkan nasabah yang menerima bunga bank sebagai penabung juga diharamkan karena dianggap memperoleh tambahan atas harta pokok tanpa berusaha. Muhammadiyah menggunakan qiyas sebagai metode ijtihad dalam merespon bunga bank. Bagi Muhammadiyah 'illat diharamkan riba adalah adanya penganiayaan (az-Zulm) terhadap peminjaman dana. Konsekuensinya adalah jika 'illat itu ada pada bunga bank maka bunga bank sama dengan riba dan hukumnya riba. Sebaliknya, jika 'illat itu tidak ada pada bunga bank maka bunga bank bukan riba, karena itu tidak haram. Bagi Muhammadiyah 'illat diharamkannya riba disinyalir juga ada pada bunga bank, sehingga bunga bank disamakan dengan riba dan hukumnya haram. Meskipun NU dan Muhammadiyah sama-sama sependapat bahwa riba hukumnya adalah haram, tetapi NU dan Muhammadiyah memiliki cara pandang atau berpikir yang berbeda. Bagi NU hukum bunga bank haram, baik bank Negara maupun swasta. Bagi Muhammadiyah, bunga bank dibolehkan dalam keadaan darurat yang merujuk pada pendapat Mustafa az-Zarqani.
\end{abstract}

\begin{abstract}
Bank interest banking in Indonesia is still a debate among Muslims with the legal status: an absolute bastard, justifiable, or other legal status. Nahdlatul Ulama (NU) and Muhammadiyah as two (2) Indonesia's largest Islamic organization tried to give legal status of bank interest. The analysis in this article is focused on the pattern of diligence conducted by both the Islamic organizations. The results show that NU perform ijtihad jama'i in determining bank interest law while leaning scholarly opinion (Shafi'ites). NU believes that interest is riba either little or a lot, there is a category ad'afan muda'afah or not. NU does not distinguish banks owned by the state or private. Even customers who receive interest bank as savers are also forbidden because they earn extra on principal assets without trying. Muhammadiyah use as a method of ijtihad qiyas in response to bank interest. For Muhammadiyah 'illat is forbidden usury persecution (az-zulm) against the borrowing of funds. The consequence is that if 'illat it exists on the bank interest rate
\end{abstract}


equal to the bank and its legal usury usury. Conversely, if the 'illat was not there at the bank interest is not usurious interest rates, because it is not haram. For Muhammadiyah 'illat Prohibition of usury was allegedly also in the interest of the bank, so the bank interest is equated with usury and haraam. Although NU and Muhammadiyah both agreed that riba is haraam, but NU and Muhammadiyah have a perspective or a different thinking. For legal NU illicit bank interest, both State and private banks. For Muhammadiyah, bank interest allowed in emergencies refers to the opinion of az-Zarqani Mustafa.

\section{Kata kunci: Riba, ljtihad Jama,I, ljtihad Qiyasi, Nahdatul Ulama (NU), dan Muhammadiyah}

\section{Pendahuluan}

Kegiatan ekonomi dari masa ke masa terus mengalami perkembangan yang memunculkan persoalan baru dalam hukum Islam kontemporer di bidang muamalah terkait dengan riba dalam transaksi perbankan. Bunga bank (interest bank) terperangkap dalam kriteria riba dalam hukum Islam, namun bank memiliki fungsi sosial yang besar.

Tujuan suatu bank mencari keuntungan yang dicapai dengan berniaga kredit. Bank memberikan kredit kepada nasabah dengan memungut bunga yang lebih besar dari yang dibayarkannya. Dalam transaski kredit itu, bunga bank merupakan tambahan yang harus dibayarkan oleh debitur kepada bank.

Fenomena di atas mendapat respon dari 2 (dua) organisasi besar Islam Indonesia dalam menyikapi masalah bunga bank tersebut, yaitu Nahdatul Ulama (NU) dalam Bahsul Masail dan Muhammadiyah dalam Majlis Tarjih. Keputusan Munas 'Alim Ulama NU di Bandar Lampung tanggal 21-25 Januari 1992 tentang hukum bunga Bank ditempuh melalui prosedur yang lebih metodologis, yakni 1) Haram, karena bunga bank dipersamakan dengan riba secara mutlak, 2) Boleh, karena bunga bank tidak dipersamakan dengan riba, 3) Subhat, kerena masih belum jelas.

Dalam menetapkan hukum bunga bank, Majlis Tarjih mengaitkan dengan masalah riba, apakah bunga bank identik dengan riba atau tidak? Untuk memastikan jawaban tersebut,
Majlis Tarjih menggunakan qiyas sebagai metode ijtihad. Bagi Muhammadiyah 'illat diharamkannya riba karena adanya pengisapan atau penganiayaan (az-Zulm) terhadap peminjaman dana. Konsekuensinya, kalau 'illat itu ada pada bunga bank, bunga bank sama dengan riba dan hukumnya riba. Sebaliknya, jika 'illat itu tidak ada pada bunga bank maka bunga bank bukan riba dan tidak haram.

Berdasarkan latar belakang masalah di atas, rumusan masalah dalam artikel ini sebagai berikut: 1 . Metode Istinbat hukum apakah yang digunakan oleh Nahdatul Ulama (NU) dan Muhammadiyah dalam menilai hukum bunga bank? 2. Bagaimana pandangan Nahdatul Ulama (NU) dan Muhammadiyah mengenai hukum bunga bank dari perspektif hujjahnya?

\section{Metode Penelitian}

Artikel ini adalah hasil penelitian, yang merupakan jenis penelitian hukum normatif atau penelitian hukum doktrinal dengan menfokuskan dari sistematika hukum. Sebagai penelitian hukum normatif maka sumber data yang dipergunakan adalah data sekunder, terdiri dari bahan hukum primer, sekunder dan tersier. Analisis data dalam penelitian ini dilakukan dengan suatu tahapan ilmiah dilakukan dengan cara kualitatif. Akhir dari pembahasan penelitian ini akan ditarik kesimpulan secara deduktif, yakni penarikan kesimpulan yang diawali oleh hal-hal yang bersifat umum kepada hal-hal yang bersifat khusus. 


\section{Pembahasan}

Dasar Hukum Penetapan Riba dan Kontekstualisasi Riba dengan Bunga Bank

Bank merupakan lembaga keuangan yang berfungsi menerima dan menyalurkan dana. Penerimaan dana masyarakat selalu dihubungkan dengan penyalurannya kepada orang atau lembaga yang memerlukan dana itu. Besarnya bunga yang diberikan oleh bank kepada investor disesuaikan dengan bunga yang diberikan kepada nasabah bank. Selisih antara bunga yang diberikan kepada investor dan bunga yang dikenakan kepada peminjam merupakan keuntungan bank itu sendiri. Biasanya bank hanya memberikan kredit kepada orang atau lembaga yang diduga kuat dapat mengembangkan usahanya yang bersifat produktif. $^{1}$

Pemilik modal dan bank mendapatkan keuntungan seiring dengan keuntungan yang diperoleh pengusaha yang meminjamkan modal. Bagi orang yang memerlukan bantuan keuangan untuk kebutuhan harian atau (misalnya untuk biaya pengobatan), tidak selayaknya menggunakan jasa bank dengan sistem bunga tersebut, sehingga perlu adanya lembaga sosial yang menyediakan dana yang bersifat non-profit. Jika kepada orang yang terakhir ini dibebankan bunga, kemungkinan adanya unsur "pemerasan" yang menjadi illat haramnya riba menjadi lebih besar.

Terjadinya riba (yang sekarang sering lebih dikenal dengan istilah bunga bank) merupakan kenyataan "normatif tekstual" yang dinyatakan jelas dalam al-Qur'an² yang didukung oleh kenyataan "historis" bahwa bunga bank telah berkembang di tengah-tengah masyarakat sebelum datangnya Islam. Ajaran Islam menolak riba dengan mengatur transaksi bisnis dengan sistem bagi hasil dalam perekonomian.

Dalam dataran pemikiran tersebut baik NU dan Muhammadiyah sepakat bahwa riba hukumnya haram karena nash sudah jelas, tetapi kedua organisasi tersebut masih berbeda pendapat dalam melihat hukum bunga bank karena pada dasarnya al-Qur'an dan al-Hadits yang tegas tentang pelarangan bunga bank tidak ada. Untuk menganalisis pernyataan NU dan Muhammadiyah tentang bunga bank, perlu dikemukakan terlebih dahulu tentang keharaman riba dalam al-Qur'an secara berangsur-angsur (tadriji) yang biasa berlaku dalam proses penetapan hukum:

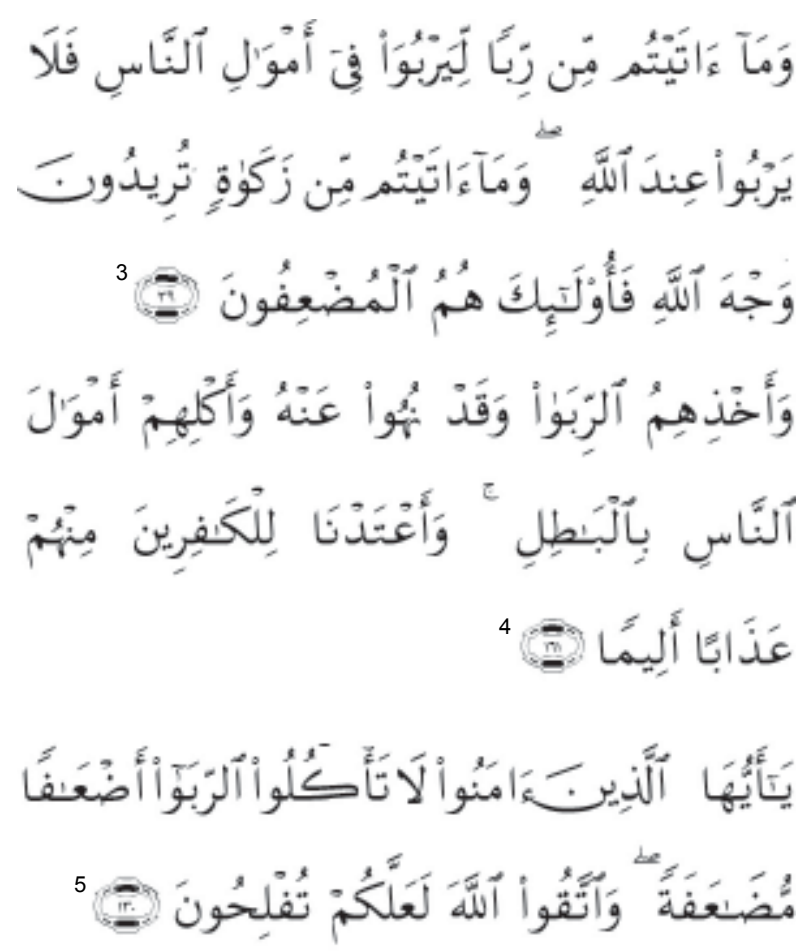

${ }^{1}$ Fathurrahman Djamil, Metode Ijtihad Majis Tarjih Muhammadiyah, Cetakan I (Jakarta: Logos Publishing House, 1995), hlm. 128.

${ }^{2}$ Ali-Imran (3) Ayat (130) dan al-Baqarah (2) Ayat (278-279).

${ }^{3}$ Ar-Rum (30) Ayat (39).

${ }^{4}$ An-Nisa' (4) Ayat (161).

${ }^{5}$ Ali Imran (3) Ayat (130). 


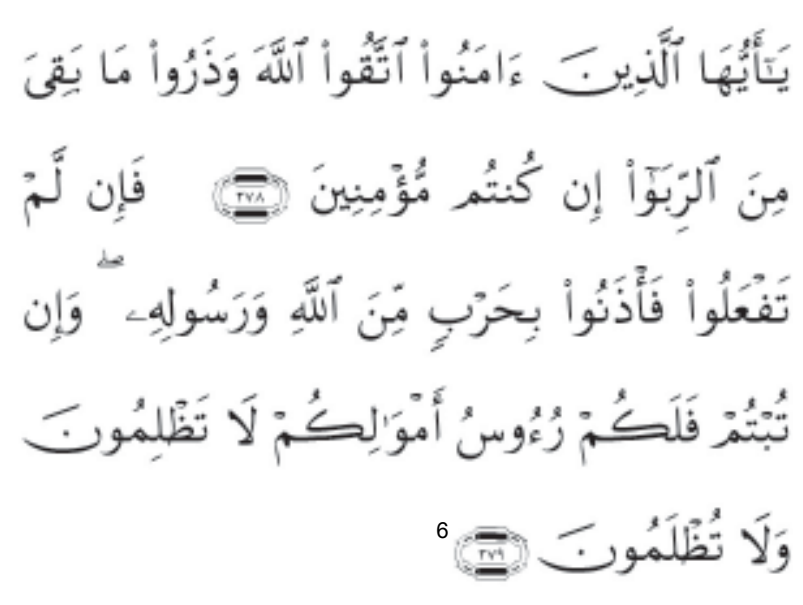

Tahapan dalam pengharaman riba dalam beberapa ayat di atas yang relevan untuk analisis dalam artikel ini pada tahap Ayat ke (3) dan ke (4). 2 Ayat yang lain masih menjadi perdebatan panjang oleh para ahli. Artikel ini menekankan pada kedua ayat tersebut. ${ }^{7}$

Ayat ke (3) dan ke (4) di atas, terlihat dengan jelas tentang pengharaman riba, namun masih bersifat parsial (juz'i), karena belum bersifat menyeluruh (kulli). Pengharaman tersebut sebatas pada katagori riba yang berlipat ganda (ad'afan muda'afah) dan sangat memberatkan bagi peminjam. Sebab turunnya (asbab an-Nuzul) ayat tersebut, menurut satu riwayat dari 'Ata' disebutkan bahwa, kaum Saqif biasa meminjamkan uang kepada keluarganya Mugirah, pada waktu jatuh tempo mereka berjanji akan membayar lebih dikemudian hari apabila diberi tenggang waktu. Dalam hukum Islam disebut dengan riba nasi'ah. ${ }^{8}$

\section{Penalaran Bayani dan Ta'lili Dalam Analisis Terhadap Bunga Bank}

Dalam Ali Imran (3) Ayat (130) terdapat kata-kata ad'afan muda'afah (berlipat ganda). Persoalannya adalah apakah kata ad'afan muda'afah dalam ayat tersebut dianggap sebagai kriteria (syarat) dalam pelarangan riba atau untuk menerangkan kondisi obyektif dan sekaligus mengecam terhadap perbuatan atau praktik riba. Menurut Fuad Zein diperlukan analisis hukum bunga bank dengan penalaran bayani dan ta'lili untuk menelusuri karakteristik riba yang disebutkan dalam al-Qur'an. ${ }^{9}$

Penalaran Bayani dalam menganalisis suratAli Imran Ayat (130) bahwa riba diberi sifat "berlipat ganda", namun tidak demikian dengan yang tersurat dalam al-Baqarah Ayat (278) menyebutkan bahwa setiap pengambilan yang melebihi jumlah pokok modal merupakan riba. Ada kesan paradok antara dua ayat di atas, sehingga ada ulama yang mengatakan, riba yang terlarang adalah yang mempunyai unsur berlipat ganda (ad'afan muda'afah), ada pula yang tidak membatasi riba harus berlipat ganda.

Dalam akhir surat al-Baqarah Ayat (278):"..... kamu tidak berbuat zalim, dan tidak pula menjadi korbannya". Jika ini dijadikan tolak ukur riba maka jalan tengah dapat ditemukan adalah betapapun kecilnya tambahan itu apabila menimbulkan kesengsaraan (zulm) termasuk riba. Pada masa Rasulullah Saw riba selalu mengambil bentuk ad'afan muda'afah, sehingga

${ }^{6} \mathrm{Al}-$ Baqarah (2) Ayat (278-279).

${ }^{7}$ Uraian tentang penjelasan ayat tersebut di atas, dapat dibaca Abu Zahra, Buhus fi ar-Riba, (ttp:Dar alBuhus al-Ilmiyyah, 1970), hlm. 25-30.

${ }^{8}$ Riba nasi'ah juga disebut riba duyun, yakni riba yang timbul akibat utang piutang yang tidak memenuhi kriteria untung muncul bersama risiko (al-Gummu bi al-Gummi) dan hasil usaha muncul bersama biaya (alKharaj bi ad-Damam). Transaksi semacam ini karena mengandung pertukaran kewajiban menanggung beban hanya karena berjalannya waktu. Heri Sudarsono, Bank dan Lembaga Keuangan Syari'ah: Deskripsi dan Ilustrasi, Cetakan I (Yogyakarta: Ekonsia, 2003), hlm. 6.

${ }^{9}$ Fuad Zein, Aplikasi Ushul Fiqh Dalam Mengkaji Keuangan Kontemporer, dalam Ainur Rafiq (ed.), Mazhab Jogja: Menggagas Paradigma Ushul Fiqh Kontemporer, Cetakan I (Yogyakarta: Ar-Ruzz, 2002), hlm. 175. 
ad'afan muda'afah relevan dengan ketidakadilan. ${ }^{10}$

Fuad Zein mengungkapkan bahwa perlu dijadikan pertimbangan pada masa Rasulullah Saw tidak ada inflasi, karena mata uang yang berlaku emas dan perak (dinar dan dirham). Oleh karena itu, pengembalian utang sebesar jumlah pinjaman menggambarkan keadilan. Pada masa sekarang inflasi melanda mata uang tertentu maka pengembalian suatu utang sebesar jumlah pinjaman tidak mengambarkan keadilan bahkan menimbulkan kerugian sepihak. Jika statemen la tazlimun wa la tuzlamun dalam al-Baqarah Ayat (278) maka pengembalian utang sebesar pinjaman berikut bunga yang proporsional dengan besarnya inflasi akan menjamin keadilan daripada tanpa tambahan. Pemahaman yang lebih adil tentang pokok modal masa sekarang untuk kasus Indonesia adalah modal yang dihitung berdasarkan nilai kurs, bukan berdasarkan nilai nominal.

Dalam penalaran Ta'lili, merujuk pada pengertian riba pada pembahasan sebelumnya, riba didefinisikan dengan kata-kata ziyadah, yakni "tambahan yang diperjanjikan atas besarnya pinjaman ketika pelunasan utang...". Jadi fokusnya adalah pada "ziyadah" sebagai ciri pokok riba.

Riba dapat juga didefinisikan dengan "tambahan atas besarnya pinjaman ketika pelunasan utang yang mendatangkan kesengsaraan pihak peminjam." Di sini titik fokusnya pada "kesengsaraan atau zulm", bukan "tambahan". "Tambahan" sebagai annau' atau spicies, sedangkan "kesengsaraan" sebagai al-jins atau genus atau 'illat. Sama halnya dengan ungkapan "khamr adalah minuman yang memabukkan" maka khamr adalah sesuatu yang didefinisikan, minuman sebagai an-nau' atau spicies, dan memabukkan sebagai al-jins atau genus atau 'illat.

Dalam analisis ini, esensi riba adalah "tambahan" dan ada juga yang mengatakan esensinya adalah zulm. Jika kembali pada persoalan larangan riba maka "tambahan" tidak memiliki makna apa-apa. Sebaliknya, ketidakadilan adalah hal yang bertentangan dengan tujuan penetapan prinsip ekonomi Islam, sehingga, 'illat pelarangan riba seharusnya adalah zulm bukan "tambahan". ${ }^{11}$

\section{Ad'afan Muda'afah Sebagai Ukuran dalam Praktik Riba}

Ahli hukum Islam yang menyatakan bahwa ad'afan muda'afah merupakan syarat keharaman riba adalah Rasyid Rida. Anwar Abbas menjelaskan tiga alasan yang dikemukakan Rida untuk membuktikan bahwa kata riba yang termaktub dalam surat alBaqarah adalah riba yang merujuk kepada riba yang berbentuk ad'afan muda'afah. ${ }^{12}$

Pertama, kaidah kebahasaan. Kaidah pengulangan kosa kata yang berbentuk makrifah berulang maka pengertian kosa kata kedua (yang diulang) sama dengan kosa kata yang pertama. Kata riba pada Ali-Imran Ayat (130) dalam bentuk makrifah demikian halnya dalam al-Baqarah Ayat (287), sehingga riba yang dimaksud pada ayat tahapan terakhir sama dengan riba yang dimaksud pada ayat pada tahapan kedua, yakni ad'afan muda'afah.

Kedua, kaidah memahami ayat yang tidak bersyarat berdasarkan ayat yang sama tetapi bersyarat. Penerapan kaidah ini pada ayat-ayat riba adalah memahami arti riba pada ayat al-

${ }^{10} \mathrm{lbid}$, hlm. 176.

${ }^{11}$ Abu Umar Faruq dan Muhammad Kabir Hassan, Riba and Islamic Banking, Journal of Islamic Economic, Banking, and Finance, Volume 7, Nomor 2, 2009, hlm. 29.

${ }^{12}$ Anwar Abbas Hukum Bunga Bank Konvensional, makalah disampaikan pada diskusi Majlis Tarjih tentang Bunga Bank, diselenggarakan oleh Pengurus Pusat (PP) Muhammadiyah, Jakarta, 22 Desember 2003, hlm. 1-2. 
Baqarah yang tidak bersyarat itu berdasarkan kata riba yang bersyarat ad'afan muda'afah pada ayat Ali Imran,sehingga yang dimaksud dengan riba pada ayat tahapan terakhir adalah riba yang berlipat ganda.

Ketiga, diamati oleh Rasyid Rida bahwa pembicaraan al-Qur'an tentang riba selalu digandengkan dengan pembicaraan tentang sedekah dan riba dinamainya sebagai "zulm" (penganiayaan atau penderitaan). Jadi, riba yang diharamkan itu adalah riba yang ad'afan muda'afah (yang berlipat ganda), sedangkan riba yang kecil seperti $8 \%$ atau $10 \%$, tidak termasuk riba yang diharamkan al-Qur'an.

Pendapat Rasyid Rida ini masih menimbulkan sebuah pertanyaan apa penambahan atau kelebihan itu tidak bersifat "berlipat ganda" menjadi tidak diharamkan oleh al-Quran? Jawaban untuk pertanyaan tersebut, menurut Quraish Syihab adalah terdapat pada kata kunci berikutnya, yakni fa lakum ru'usu amwalikum (bagimu modal-modal kamu) dalam Al Baqarah Ayat (279). Dalam arti bahwa yang berhak mereka peroleh kembali hanyalah modalmodal mereka. Jika demikian, setiap penambahan atau kelebihan dari modal yang dipungut dalam kondisi yang sama dengan apa yang terjadi pada masa turunnya ayat-ayat riba ini tidak dapat dibenarkan. Kata kunci ini menetapkan bahwa segala bentuk penambahan atau kelebihan baik berlipat ganda atau tidak dalam sebuah transaksi, telah diharamkan oleh al-Quran dengan turunnya ayat tersebut. Kata ad'afan muda'afah bukan syarat tetapi sekadar penjelasan tentang riba yang sudah lumrah mereka praktikkan. ${ }^{13}$

Solusi atas penindasan terhadap orangorang yang membutuhkan dengan sedekah, bukan pinjaman yang memberatkan yang berpeluang ke arah pinjaman yang berlipat ganda. Pada al-Baqarah Ayat (280) ditegaskan bahwa, "jika orang yang berutang tidak mampu membayar pada waktu yang ditetapkan maka berilah tangguh sampai ia berkelapangan". Kelebihan yang dipungut dalam bentuk pelipatgandaan merupakan penganiayaan terhadap peminjam. ${ }^{14}$

Ketika membahas ad'afan muda'afah, pakar hukum Islam Ali ash-Shabuni mengatakan bahwa pertama, lafaz tersebut bukanlah qayyid dan syarat. Tujuan dari ungkapan ini hanya menerangkan tentang praktik yang dilakukan orang-orang Jahiliyah Arab pra-Islam. Kedua, kaum muslimin telah sepakat tentang pengharaman riba baik sedikit maupun banyak. Pengharaman riba yang sedikit karena dari yang riba sedikit mendorong riba yang banyak. AshShabuni beralasan, Islam ketika mengharamkan seluruhnya (kulli) sebab kaidah sadd azzari'ah, dan kebolehan yang sedikit niscaya akan menarik kepada yang banyak.

Penafsiran-penafsiran para ahli di atas dapat dikatakan bahwa riba yang dilarang Allah dalam ayat-ayat al-Quran adalah bersifat umum, tidak membedakan sedikit atau banyak, produktif atau konsumtif. Jenis riba ini adalah riba yang telah dipraktikkan dalam sistem perekonomian masyarakat jahiliyah Arab praIslam. Dengan demikian, akad perdagangan yang dibebankan bunga terhadap debitur oleh kreditur tetap haram.

\section{Keharaman Riba Dalam Perspektif Nahdatul Ulama (NU) dan Muhammadiyah}

Pemberian kredit oleh bank kepada nasabah mempersyaratkan bunga tertentu dalam persentase pinjamannya. Bahkan apabila nasabah tidak dapat melunasi kredit

${ }^{13}$ M. Quraish Syihab, Membumikan Al-Qur'an: Fungsi dan Peran Wahyu dalam Kehidupan Masyarakat, Cetakan XXVI, (Bandung: Mizan, 2003), hlm. 266.

${ }^{14}$ Nur Chamid, Problematika Riba dan Bunga Bank, Jurnal Empirisma, Volume 14, Nomor 2, 2005, hlm. 131. 
pada waktu yang telah ditentukan oleh pihak bank (kreditur) maka pinjaman itu bisa menjadi berlipat ganda. Nasabah yang dibebani bunga, kemungkinan adanya unsur "penambahan atas jumlah pinjaman dengan tenggang waktu" menjadi lebih besar, sehingga pembebanan tambahan atas pokok pinjaman menjadi riba. ${ }^{15}$

Pemberian bunga oleh bank atas simpanan para nasabah dan diberikannya dalam persentasi oleh pihak bank sendiri untuk kepentingan para nasabahnya, sepanjang para nasabah tidak mempersyaratkan tambahan bunga kepada bank tentu tidak dikategorikan sebagi riba. Pemberian bunga tersebut atas kehendak bank sebagai debitur.

NU menyatakan bahwa menitipkan uang di bank dengan alasan demi keamanan dan uangnya tidak digunakan untuk larangan agama adalah makruh. ${ }^{16}$ Pernyataan NU ini tidak disertai dengan ungkapan yang jelas, yakni pada kalimat "larangan agama". Tampaknya batasan "larangan agama" yang dimaksud adalah meliputi larangan bagi pihak bank untuk menyalurkan uang kepada debitur yang memakai jasa bank dengan tambahan pinjaman atau pihak bank sebagai kreditur meminjamkan dana kepada perseorangan (bunga konsumtif). Jadi, apabila bank tempat para nasabah menyimpan uang untuk larangan agama, NU tetap mengharamkan praktik bunga bank tersebut.

NU sependapat dengan Yusuf alQardawi yang menyatakan bahwa bunga yang diambil oleh penabung di bank adalah riba yang diharamkan. Artinya, apa yang diambil seseorang tanpa melalui usaha perdagangan dan tanpa bersusah payah sebagai tambahan pokok hartanya adalah riba. Akibatnya seseorang tidak boleh memberikan zakat atau bersedekah dengan hasil bunga bank tersebut.

Berbeda dengan NU, Muhammadiyah tampaknya masih ragu terhadap ada atau tidak adanya 'illat riba pada bank milik Negara. Muhammadiyah berpendapat bahwa hukum bunga bank milik Negara merupakan musytabihat. Alasannya karena ada kecenderungan halal atau haram, ${ }^{17}$ di samping juga karena dalam bank itu tidak dibedakan antara orang yang meminjam uang untuk konsumsi dan meminjam untuk produksi.

Keputusan Muhammadiyah ini sejalan dengan pendapat yang mengatakan bahwa bunga bank boleh karena darurat seperti pendapat Mustafa az-Zarqani. Menurut azZarqani, bank merupakan kenyataan yang tidak dapat dihindarkan, sehingga umat Islam boleh bermu'amalah dengan bank atas pertimbangan darurat. ${ }^{18}$ Muhammadiyah menyatakan bahwa riba yang diharamkan oleh agama adalah sifat pembungaan yang selalu disertai unsur penyalahgunaan kesempatan dan penindasan, sedangkan yang berlaku dewasa ini sama sekali tidak menimbulkan rasa penindasan atau kekecewaan oleh siapapun yang berkepentingan. ${ }^{19}$

Menurut Muahmmadiyah, 'illat haramnya riba adalah pemerasan (zulm) yang dapat dijadikan sebagai dasar penetapan hukum yang

${ }^{15}$ Mohammad Anton Athoillah, Ekonomi Islam: Transaksi dan Problematiknya, Ijtihad, Jurnal Wacana Hukum Islam dan Kemanusiaan, Volume 13, Nomor 2, Desember 2013, hlm. 269. Mohammad Anton Athoillah dan Sofyan al Hakim, Reinterpreting The Ratio Legis of Prohibition of Usury, Middle East Journal of Scientific Research, Volume 14, Nomor 10, 2013, hlm. 1390.

${ }^{16} \mathrm{Abu}$ Hamdan Abdu al-Jalil Hamid, Ahkam al-Fuqaha' fi al-Muqarrarat Mu'tamarat Nahdatu al-Ulama', Juz II, (Semarang: Toha Putra, t.t.), hlm. 71.

${ }^{17}$ Pimpinan Pusat Muhammadiyah, Himpunan Putusan Majlis Tarjih Muhammadiyah, (Yogyakarta: Persatuan, t.t), hlm. 304-305. Lihat juga Fathurrahman Djamil, Metode ljtihad...., Op. Cit., hlm. 129.

${ }^{18}$ A. Wahid Zaini, Dunia Pemikiran Kaum Santri, (Yogyakarta: LKPSM: 1994), hlm. 71.

${ }^{19}$ Pimpinan Pusat Muhammadiyah, Himpunan...,Op.Cit., hlm. 305. 
tegas bahwa bunga bank negara itu haram atau halal. Apabila 'illat itu ada maka dapat dinyatakan bahwa bunga adalah haram, dan apabila tidak ada 'illat maka bunga bank dapat dinyatakan halal. ${ }^{20}$ Alasan yang mendasari Muhammadiyah masih ragu untuk menetapkan kehalalan bunga bank Negara karena adanya pendapat anggota panitia perumus hasil mu'tamar tarjih yang menyatakan bahwa dalam masyarakat terdapat praktik pembungaan uang yang berlaku pada salah satu bank swasta di Indonesia. Seseorang yang menitipkan sejumlah uang pada bank tersebut untuk memperoleh bunga tiap bulannya sebanyak 10 $\%$, kemudian bank itu memberikan pinjaman kepada pedagang dengan menarik bunga sebesar $15 \% .^{21}$

Gambaran dalam keadaan ekonomi seperti di Indonesia dewasa ini, besar sekali adanya kemungkinan pedagang meminjamkan lagi uang pinjaman itu kepada pihak keempat untuk mendapatkan keuntungan bunga lagi. Sebenarnya, jika praktik itu ada, tindakan itu telah menyalahi ketentuan yang telah ditetapkan oleh Bank Indonesia (BI). Dalam ketentuan itu disebutkan bahwa suku bunga maksimal pada saat Majlis Tarjih bermu'tamar adalah $18 \%$ pertahunnya. Jadi tindakan tersebut merupakan penyimpangan dari peraturan yang berlaku. ${ }^{22}$

Asumsi yang menguatkan bahwa Muhammadiyah pada dasarnya cenderung kepada halalnya bunga bank milik negara, dikuatkan oleh pengamatan Kasman Singodimedjo (wakil ketua-III PP. Muhammadiyah periode 1971-1974) terhadap putusan Majlis Tarjih tentang bunga bank itu. Menurut pengamatannya, Muhammadiyah sebenarnya sudah membenarkan praktik bank konvensional (yang memakai sistem bunga). Argumentasi yang dimajukannya adalah bahwa penjelasan Majlis Tarjih Muhammadiyah tentang bunga bank disebutkan: "kecuali apabila ada suatu kepentingan masyarakat atau kepentingan pribadi yang sesuai dengan maksud dari tujuan agama Islam pada umumnya maka tidak ada halangan perkara musytabihat tersebut dikerjakan sekedar sesuai dengan kepentingan itu". ${ }^{23}$

Pertanyaan yang diajukan oleh Kasman Singodimedjo apakah ketika putusan itu diambil telah terdapat kepentingan-kepentingan seperti yang disebutkan di atas? Ternyata, jawabannya telah terdapat dalam konsideran dan penjelasan dari putusan tersebut. Di antara konsideran dan penjelasan yang menjawab persoalan tersebut sebagai berikut: ${ }^{24}$

"1. Konsideran "mengingat" nomor 2: "bahwa fungsi bunga bank dalam perekonomian modern sekarang ini bukan hanya menjadi sumber penghasilan bagi bank, melainkan juga berfungsi sebagai alat politik perekonomian negara untuk kesejahteraan umat (stabilitasi ekonomi)".

2. Konsideran "menimbang" nomor 3: "bahwa hasil keuntungan bank-bank milik negara pada akhirnya akan kembali untuk kemaslahatan umat".

3. Konsideran "menyadari" nomor 3: "bunga adalah sendi dari sistem perbankan yang berlaku selama ini".

4. Konsideran "menyadari" nomor 1: "bahwa bank dalam sistim ekonomi pertukaran adalah mempunyai fungsi yang vital bagi perekonomian pada masa sekarang".

5. Konsideran "menyadari" nomor 4: "bahwa umat Islam sebagai umat pada dewasa ini

\footnotetext{
${ }^{20}$ Fathurrahman Djamil, Metode Ijtihad..., Op.Cit., hlm. 129.

${ }^{21}$ Pimpinan Pusat Muhammadiyah, Himpunan..., Op.Cit., hlm. 307.

${ }^{22}$ Fathurrahman Djamil, Metode Ijtihad..., Op.Cit., hlm. 133.

${ }^{23}$ Ibid.

${ }^{24}$ Pimpinan Pusat Muhammadiyah, Himpunan..., Op.Cit., hlm. 307.
} 
tidak dapat melepaskan diri daripada pengaruh perbankan yang lansung atau tidak langsung mengenai perekonomian umat Islam".

6. Konsideran "mengingat" nomor 3: "bahwa adanya undang-undang yang mengatur besar kecilnya bunga adalah untuk mencegah terjadinya penghisapan pihak yang kuat terhadap yang lemah, di samping untuk melindungi berlangsungnya kehidupan bank itu sendiri".

7. Penjelasan dari mu'tamar tarjih sendiri: "bank negara dianggap badan yang mencakup hampir semua kebaikan dalam alam perekonomian modern dan dipandang memiliki norma yang menguntungkan masyarakat dibidang kemakmuran. Bunga yang dipungut dalam sistem perkreditan adalah sangat rendah sehingga sama sekali tidak ada pihak yang dikecewakan".

8. Penjelasan dari mu'tamar tarjih sendiri: "...tetapi terang diinsafi bahwa segi positif daripada bank perkreditan sangat besar bagi dunia perekonomian".

9. Penjelasan dari mu'tamar tarjih sendiri: “...sedang (pembangunan) yang berlaku selama ini sama sekali tidak menimbulkan rasa penindasan atau kekecewaan oleh siapapun yang bersangkutan".

\section{Istinbat Hukum Nahdatul Ulama (NU) Dalam Penetapan Bunga Bank Sebagai Riba}

NU memiliki metode pemahaman dalil (istinbat) dalam memutuskan atau menetapkan suatu hukum. Penetapan suatu hukum tidak dapat dilakukan secara tergesa-gesa tanpa menggunakan kaidah-kaidah yang telah ditetapkan dalam hukum Islam. Penetapan suatu hukum hanya dapat dilakukan oleh orang-orang yang telah memenuhi kapasitas berijtihad.

ljtihad dapat dikatakan sebagai upaya berfikir secara optimal dalam menggali hukum Islam dari sumbernya untuk memperoleh jawaban terhadap permasalahan hukum yang muncul dalam masyarakat. ${ }^{25}$ ljtihad dipengaruhi oleh perubahan-perubahan sosial yang harus diberi arah oleh hukum sehingga dapat mewujudkan kemaslahatan umat manusia.

Ijtihad dalam kehidupan manusia merupakan kebutuhan yang bersifat kontinuitas dan situasi masyarakat yang senantiasa mengalami perubahan dan perkembangan. ljtihad yang benar dapat menjelaskan kehendak agama (maqasid at-tasyri') dengan kebutuhan masyarakat. Oleh karena itu, hukum Islam sebagai produk ijtihad hendaknya mampu mengelaborasikan nilai-nilai dan aturan normatif yang telah mentradisi dalam sebuah tatanan suci (syari'ah) yang telah menjadi landasan hidup beragama.

Suatu hukum hendaknya dapat memainkan peranan ganda yang sama-sama penting. Pertama, hukum dapat dijadikan sebagai kontrol sosial terhadap perubahan-perubahan yang berlangsung dalam kehidupan manusia. Kedua, hukum dapat dijadikan sebagai alat rekayasa sosial dalam rangka mewujudkan kemaslahatan umat manusia, sebagai tujuan hakikat hukum itu sendiri. ${ }^{26}$

Bunga bank pada hakikatnya berada pada level peraturan syar'i dan kondisi masyarakat (sosio kultural) yang diturunkan menjadi berbagai interpretasi. Pandangan NU dan Muhammadiyah sebenarnya bermuara pada nash yang sama mengenai riba, yakni

${ }^{25}$ Muhammad Muflih, Rekonstruksi Pemahaman Terhadap Konsep Riba Pada Transaksi Perbankan Konvensional, Jurnal Ahkam, Volume XIII, Nomor 1, Januari 2013, hlm. 22. Lihat juga Abdul Wahab Khallaf, 'Ilm Usul Fiqh (Kairo: Dar al-Kuwaitiyyah, 1968), hlm. 216.

${ }^{26}$ Soerjono Soekamto, Pokok-pokok Sosiologi Hukum (Jakarta: Rajawali Press, 1980), hlm. 115-116. 
Surat Ali Imran Ayat (130) dan al-Baqarah Ayat (278-279).

Persoalan riba tidak dapat lepas dari teori pembungaan uang. Identifikasi ini juga telah begitu kuat di masyarakat. Bunga (interest) dalam institusi keuangan dewasa ini menjadi instrumen yang sangat urgen dihampir sistem ekonomi dunia. Bunga (interest) telah diterima sebagai suatu kewajaran dan dianggap sebagai salah satu ciri perekonomian modern. Bahkan bunga telah menjadi daya tarik tersendiri bagi masyarakat untuk dinikmati dan dimanfaatkan dalam proses perputaran keuntungan dan kegiatan bisnis. Lembaga-lembaga keuangan internasional seperti IMF dan IDB sebagai lembaga perantara antara sektor riil dan moneter telah mendesain sedemikian rupa untuk menjadikan bunga supaya bisa merangsang terlaksananya tabungan dan kredit baik konsumtif dan produktif. ${ }^{27}$

Kredit dari bank yang dimaksudkan untuk usaha produktif yang menghasilkan keuntungan kepada debitur seharusnya perlu ditinjau kembali. Tidak ada jaminan bahwa pinjaman selamanya mendapat keuntungan dari usahanya, sedangkan bunga akan terus dikenakan selama masih ada simpanan atau pinjaman, tidak terbatas jangka waktunya dan pihak bank tidak melihat, apakah peminjam mendapat keuntungan atau rugi dari pinjaman tersebut. Dengan sistem bunga, kelihatan pihak pemberi pinjaman (kreditur) membiarkan wiraswastawan menanggung risiko ketidakpastian yang sebenarnya menjadi risiko kedua belah pihak. Keadaan semacam ini yang menggambarkan ketidakadilan diantara kedua belah pihak.

NU berpendapat bahwa pihak debitur yang bertransaksi dengan bank harus bertanggung jawab penuh atas uang yang dipinjamnya dan bunganya ditentukan atas dasar untung rugi atau besar kecilnya keuntungan dari hasil usahanya. Transaksi tersebut termasuk aqad qard dan dengan sendirinya bunga bank yang terikat aturan haram hukumnya, karena termasuk riba qard. NU berpendapat bahwa setiap pinjaman kredit yang menarik manfaat yang diberikan oleh debitur yang dipersyaratkan oleh kreditur, bukan merupakan kebaikan hati dari pihak debitur. Karena hal ini juga bertentangan dengan firman Allah:

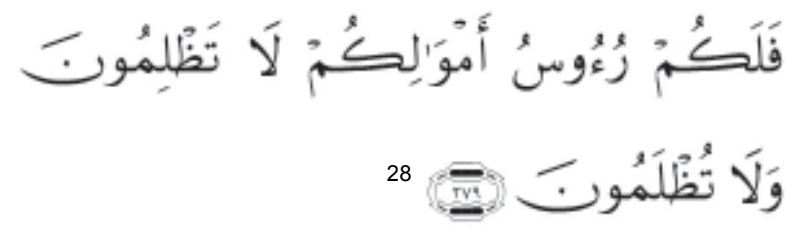

Ikhtiar dari permasalahan itu tidak terlepas dari praktik riba dalam pemikiran hukum, bukan pada ayat-ayat mengenai keharaman riba itu sendiri, melainkan pada benda-benda yang boleh atau tidak tatkala dilakukan secara riba. Hal ini bermula dari tidak adanya permasalahan yang muncul menyangkut pemahaman masalah riba nasi'ah dikalangan para ulama dalam kurun waktu yang lama sebagaimana yang telah dipraktikkan oleh kaum jahiliyah pra-Islam. Hadits yang menjadi dasar para ulama untuk riba sebagai berikut:

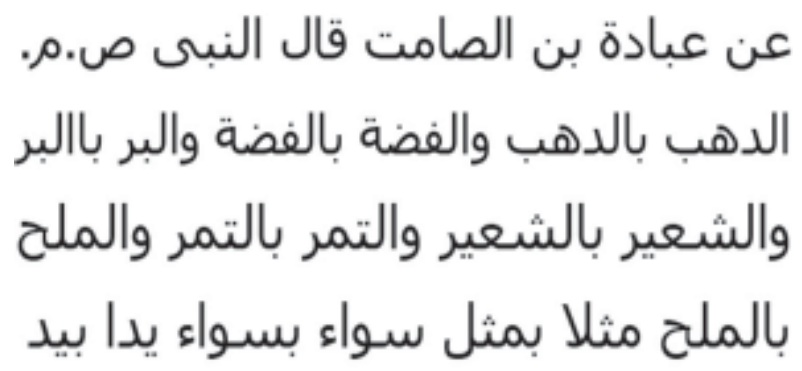

\footnotetext{
${ }^{27}$ Abd. Salam Arief, Bank Islam: Suatu Alternatif Pemberdayaan Ekonomi Umat, Jurnal Asy-Syir'ah, Volume 6, Nomor 7. 2000, hlm. 63-64.

${ }^{28}$ Al-Baqarah (2) Ayat 279.
} 
فادا احتلفت هده الاصناف فبيعوا كيف شئتم ادا كان يدا بيد

Rumusan yang digunakan para ulama terhadap ketidakbolehan terjadi riba nasi'ah pada kebutuhan jenis barang tersebut, bila dibandingkan dengan rumusan mufassirin tidak ada perbedaan, dan rumusan itu dapat dilihat bahwa riba nasi'ah mempunyai unsur: 1 . Terjadi karena peminjaman dalam jangka waktu tertentu. 2. Pihak peminjam berkewajiban memberi tambahan kepada debitur untuk mengangsur atau melunasi, sesuai dengan pinjaman. 3. Obyek peminjaman berupa benda ribawi. ${ }^{30}$

Berdasarkan uraian di atas, dapat ditarik kesimpulan bahwa menurut metode pengambilan hukum yang dilakukan NU mengikuti prosedur pengambilan dengan cara ilhaq al-masail bi nazairiha. NU menjadikan riba qard sebagai mulhaq 'alaihi, transaksi bank adalah mulhiq. Hukum mulhaq 'alaihi adalah haram dan wajh al-'ilhaqnya adalah timbangan atau takaran dan juga standar harga emas dan perak atau harga saja. Kecenderungan pernyatan NU ini agaknya memperlihatkan corak pemahaman hukum Islam yang dikembangkan oleh Idrus Syafi'i.

NU menetapkan hukum bunga bank diharamkan baik kecil atau besar, sedikit atau banyak. Keharaman yang berlipat ganda atau besar, hukumnya sama dengan ad'afan muda'afah (riba jahiliyyah), yakni haram li zatihi. Adapun bunga yang kecil atau sedikit termasuk riba khafi yang hukumnya haram karena untuk menutup riba yang besar haram li sadd azzari'ah.

\section{Istinbat Hukum Muhammadiyah Dalam Penetapan Bunga Bank Sebagai Riba}

Muhammadiyah dalam menetapkan bunga bank bermaksud menggunakan qiyas sebagai metode penetapan hukumnya. Bagi Muhammadiyah, 'illat diharamkannya riba karena adanya penganiayaan terhadap pihak peminjam. Konsekuensinya, jika'illat itu ada pada bunga bank maka bunga pada bank sama dengan riba dan hukumnya haram. Sebaliknya, jika'illat tidak ada pada bunga bank maka bunga bank bukan riba, karena itu tidak haram. ${ }^{31}$

Untuk memahami masalah ini secara utuh, berikut ini dijelaskan cara kerja qiyas dalam menetapkan kasus bunga bank. 'Asl dalam kasus ini adalah riba yang terdapat dalam al-Quran. Far'u-nya adalah bunga bank. Hukmu al-Asl-nya adalah bahwa riba itu hukumnya haram. 'Illat diharamkannya riba adalah zulm atau penghisapan dan pemerasan terhadap peminjam. Menurut Muhammadiyah, oleh karena riba itu telah terdapat pada bunga bank maka bunga bank sama dengan riba dan hukumnya haram. Tetapi, kesimpulan ini hanya berlaku untuk bank swasta. Adapun bunga bank pada bank-bank milik negara, 'illat-nya belum meyakinkan, sehingga menurut Muhammadiyah, hukum bunga bank milik pemerintah adalah musytabihat, tidak haram dan tidak pula halal secara mutlak. ${ }^{32}$

Illat adalah sifat tertentu yang dapat diketahui secara objektif (zahir), dapat diketahui tolak ukurnya (mundabit), dan sesuai dengan

\footnotetext{
${ }^{29} \mathrm{Al}-$ Imam Abul Husain Muslim bin al-Hajjaj al-Qusyairi an-Naisaburi, Sahih Muslim, Bab as-Sarf wa Bai' az-Zahab bi al-Waraq Naqdan, (Bandung: al-Ma'arif, t.t.), hlm, 692. Lihat juga al-, afiz Ibnu Hajar al'Asqalani, Bulugu al-Maram, Juz I, (Surabaya: al-Hidayah, t.t.), hlm. 170.

${ }^{30}$ Muhammad Zuhri, Riba dalam al-Qur'an dan Masalah Perbankan: Sebuah Tilikan Antisipatif, Cetakan I (Jakarta: Raja Grafindo, 1996), hlm. 109.

${ }^{31}$ Fathurrahman Djamil, Metode ljtihad..., Op.Cit, hlm. 125-126.

32Pimpinan Pusat Muhammadiyah, Himpunan..., Op. Cit, hlm. 304-306.
} 
ketentuan hukum (munasib). 'illat dapat diambil dari hikmah ditetapkannya hukum. Hikmah baru dapat ditetapkan sebagai 'illat jika terdapat mazhinnat atau indikator yang menunjukkan bahwa hikmah itu telah ada pada kasus tersebut. Hubungannya dengan masalah riba, apakah sifat zulm itu sudah dapat dikatakan 'illat atau baru hikmah? Jika sudah termasuk 'illat apakah indikator yang menunjukkan hal tersebut? Dengan memperhatikan praktik riba pada masa ayat al-Quran ini diturunkan, dapat dipahami bahwa pemerasan merupakan hikmah diharamkannya riba. Hikmah ini dapat menjadi 'illat setelah adanya mazhinnat, yakni bahwa tambahan itu dipersyaratkan ketika transaksi utang-piutang itu berlangsung. Oleh karena itu,'Illat ini tidak secara eksplisit disebutkan dalam al-Quran maupun al-Hadits maka kedudukannya termasuk 'illat mustanbatah, dan bukan 'illat mansusat. Ketika Muhammadiyah menyatakan bahwa'illat diharamkan riba adalah pemerasan kreditur kepada debitur, tentu sudah melalui proses pencarian 'illat, atau yang dalam ushul fiqih dikenal sebagai masalik al-'illat. ${ }^{33}$

Secara garis besar proses penemuan 'illat dapat dilakukan melalui tiga tahap. Tahap pertama adalah takhrij al-manat, yakni menginventarisasi beberapa sifat yang dapat dijadikan 'illat. Tahap kedua adalah tanqih almanat, yakni menyeleksi beberapa sifat yang telah diinventarisasi pada tahap pertama. Tahap ketiga adalah tahqiq al-manat, yakni membuktikan keefektifan 'illat haramnya riba, apakah dapat diterapkan dalam kasus bunga bank atau tidak. ${ }^{34}$

Berdasarkan cara kerja itu, pertama sekali dicari dan dihimpun beberapa sifat yang dapat dijadikan 'illat haramnya riba. Pada tahap ini diperoleh informasi bahwa sifat yang dapat dijadikan riba adalah pemerasan atau penganiayaan (istiglal wa az-zulm), tambahan tanpa risiko (ziyadah al-Khaliyat 'an al-'Iwad) dan tambahan yang berlipat ganda (ziyadah alMuda'afat). Tahap berikutnya diadakan seleksi, mana di antara ketiga sifat itu yang dianggap relevan. Dalam tahap ini, dapat diketahui bahwa sifat "tambahan tanpa risiko" tidak dapat dijadikan 'illat, karena ternyata Nabi sendiri pernah memberikan kelebihan pembayaran kepada kreditur. Begitu pula sifat "tambahan yang berlipat ganda" semata-mata tidak dapat dijadikan 'illat, karena Allah SWT menyatakan "wa in tubtum falakum ru'usu amwalikum". Dari sini tinggalah sifat "pemerasan dan penganiayaan" yang dapat dijadikan 'illat haramnya riba. Sifat yang terakhir ini, di samping dapat dilihat dalam sabab an-Nuzul ayat terakhir tentang riba, juga diisyaratkan oleh ungkapan al-Quran sendiri: "la tazlimuna wa la tuzlamun". ${ }^{35}$

Melalui proses pencarian 'illat seperti di atas dapat disimpulkan bahwa pemerasan dan penganiayaan merupakan 'illat diharamkannya riba. 'Illat di sini masih perlu diteliti lagi, dalam kaitannya dengan penerapan kasus bunga bank, karena sifat itu belum dapat diketahui tolak ukurnya (mundabit). Untuk itu, ditetapkan ketentuan bahwa unsur pemerasan itu telah dianggap ada manakala ada "perjanjian pada awal transaksi utang piutang itu". Persyaratan ini dianggap sebagai mazinnat, yakni pemerasan. Inilah yang dianut mayoritas oleh ahli ushul fiqh. ${ }^{36}$

Pernyataan Muhammadiyah mengenai bunga bank seperti di atas tidak lepas dari komitmennya untuk menggunakan tolak ukur

\footnotetext{
${ }^{33}$ Fathurrahman Djamil, Metode ljtihad..., Op.Cit, hlm. 127.

${ }^{34} \mathrm{Ibid}$.

${ }^{35} \mathrm{lbid}$.

${ }^{36}$ Ibid, hlm. 128.
} 
kemaslahatan yang menjadi tujuan utama disyariatkan hukum dalam Islam. Menurut pendapatnya, bahwa kepentingan dan kebutuhan umat Islam tidak boleh diabaikan. Dalam kondisi demikian, kemungkinan terjadinya kemiskinan dikalangan umat Islam akan semakin besar pula. Tidak mustahil hal ini akan membawa kepada kekufuran. Jadi, menjaga stabilitas ekonomi umat Islam berarti menjaga keutuhan agama yang dianut mereka. Menjaga harta dari kepunahan dan menjaga agama merupakan aspek esensial (daruriyat). ${ }^{37}$

Muhammadiyah menggunakan qiyas sebagai metode penetapan hukum bunga bank. Hikmah dan 'illat, yang menjadi faktor penentu dalam metode ini, dipahami oleh organisasi ini sebagai satu istilah yang tidak dapat dipisahkan satu sama lain. Oleh karena itu, Muhammadiyah mengalami kesulitan untuk memutuskan kasus bunga bank ini. Selain itu, organisasi ini juga menggunakan istihsan bi addarurat sebagai metode penetapan hukum bunga bank. Namun, metode ini juga tidak sepenuhnya ditetapkan. Baginya, meskipun berdasarkan qiyasjali ternyata bunga bank itu sama dengan riba, tapi demi kepentingan umat Islam maka hukum haram riba tidak dapat diterapkan sepenuhnya pada kasus bunga bank. ${ }^{38}$

\section{Kesimpulan}

Berdasarkan analisis dalam pembahasan di atas, artikel ini dapat menyimpulkan hasil analisis sebagai berikut:

1. NU telah melakukan ijtihad (jama'i) ketika menghadapai persoalan hukum Islam kontemporer terkait dengan bunga bank. $\mathrm{NU}$ tidak meninggalkan metode yang biasa digunakan di lingkungan NU, yakni bermazhab secara qauli dengan mengambil pendapat ahli hukum Syafi'iyah . ljtihad bagi NU dilakukan dalam persoalan hukum Islam yang tidak ditemukan dalam kitab-kitab mu'tabar. Penerapkan metode ijtihad jama'l yang telah dibangun oleh ulama terdahulu dijadikan sebagai sandaran penetapan hukum bunga bank dalam praktik perbankan di Indonesia. NU berpendapat bahwa hukum bunga bank adalah haram karena termasuk utang yang dipungut dengan memberikan pembebanan yang berlebihan kepada peminjam atau nasabah (ad'afan muda'afah).

2. Sementara Muhammadiyah menggunakan qiyas sebagai metode ijtihad dalam merespon bunga bank. Bagi Muhammadiyah 'illat diharamkannya riba adalah adanya penganiayaan (az-Zulm) terhadap peminjaman dana. Konsekuensinya adalah jika 'illat itu ada pada bunga bank maka bunga bank sama dengan riba dan hukumnya riba. Sebaliknya, jika 'illat itu tidak ada pada bunga bank maka bunga bank bukan riba dan tidak haram. Bagi Muhammadiyah 'illat diharamkannya riba disinyalir juga ada pada bunga bank, sehingga bunga bank disamakan dengan riba dan hukumnya adalah haram. Namun, keputusan tersebut hanya berlaku untuk bank milik swasta. Adapun bunga bank yang diberikan oleh bank milik Negara pada para nasabahnya atau sebaliknya, termasuk perkara musytabihat, tidak haram dan tidak pula halal secara mutlak. Pendapat Muhammadiyah mengacu pada hasil mu'tamar Majlis Tarjih Muhammadiyah di Sidoarjo Jawa Timur, tahun 1968 yang memutuskan: Pertama, riba hukumnya haram dengan nash sarih al-Qur'an dan as-Sunnah. Kedua, bank dengan sistem

${ }^{37}$ Ibid, hlm. 129.

${ }^{38} \mathrm{Ibid}$, hlm. 133. 
riba hukumnya haram dan bank tanpa riba hukumnya halal. Ketiga, bunga yang diberikan oleh bank milik negara kepada para nasabahnya atau sebaliknya, termasuk perkara musytabihat (yang meragukan). Keempat, menyarankan pada Pimpinan Pusat (PP) Muhammadiyah untuk mengusahakan terwujudnya konsepsi sistem perekonomian, khususnya lembaga perbankan, yang sesuai dengan kaidah Islam.

3. Baik NU maupun Muhammadiyah samasama sependapat bahwa riba hukumnya adalah haram hal ini berdasarkan alQur'an dan Hadits yang dengan tegas telah mengharamkan riba. Meskipun keduanya dalam melihat aplikasi hukum Islam tentang riba sama-sama mengharamkannya, tetapi NU dan Muhammadiyah memiliki cara berpikir yang berbeda. Bagi NU bahwa hukum bunga bank adalah haram, baik itu bank milik swasta maupun bank milik Negara. Lebih lanjut, NU mengungkapkan bahwa bunga yang diambil oleh penabung di bank adalah riba yang diharamkan. Artinya, apa yang diambil seseorang tanpa melalui usaha perdagangan dan tanpa bersusah payah sebagai tambahan pokok hartanya maka yang demikian itu termasuk riba. NU kemudian menguatkan pendapatnya bahwa pengambilan bunga bank oleh nasabah yang menyimpan uangnya di bank adalah haram. Dalam hal ini NU lebih tegas dalam menetapkan keharaman bunga bank, yakni apabila pihak bank menggunakannya untuk perbuatan yang telah dilarang agama. Berbeda dengan NU, bagi Muhammadiyah agaknya masih ragu terhadap ada atau tidak adanya 'illat riba pada bank milik Negara. Hukum bunga bank milik negara adalah musytabihat. Alasan mengatakan musytabihat karena ada dua kecende- rungan, yaitu halal atau haram. Di samping itu, karena dalam bank itu tidak dibedakan antara orang yang meminjam uang untuk konsumsi dan meminjam untuk produksi, sehingga harus dihindari, kecuali dalam keadaan darurat (terpaksa). Tampaknya keputusan Muhammadiyah ini sejalan dengan pendapat yang mengatakan bahwa bunga bank boleh karena darurat, seperti pendapat Mustafa az-Zarqani, yang mengatakan bahwa bank merupakan kenyataan yang tidak dapat dihindarkan. Oleh karena itu, umat Islam boleh bermu'amalah dengan bank atas pertimbangan darurat. Muhammadiyah menyatakan bahwa riba yang diharamkan oleh agama adalah sifat pembungaan yang selalu disertai unsur penyalahgunaan kesempatan dan penindasan, sedangkan yang berlaku dewasa ini sama sekali tidak menimbulkan rasa penindasan atau kekecewaan oleh siapapun yang berkepentingan.

\section{Saran}

Saran dalam artikel ini diberikan kepada pemangku kepentingan terutama NU dan Muhammadiyah sebagai organisasi besar umat Islam di Indonesia sebagai berikut:

1. Dalam melihat permasalahan hukum Islam yang akan diberi ketetapan norma hukumnya, baik NU maupun Muhammadiyah hendaknya mengkaji permasalahan yang ada tersebut dari berbagai sudut pandang yang menyangkut hakikat permasalahan, latar belakang sosial, ekonomi politik, budaya dan yang semisalnya dengan tidak mengesampingkan al-Qur'an dan Hadits sebagai rujukan utama dalam menetapkan hukum Islam. Karena fiqh sebagai suatu bentuk ketetapan hukum akan selalu berubah sesuai dengan masyarakat yang 
dihadapinya (salih li kulli zaman wa makan). Dalam memberikan norma hukum yang ada dapat bersesuaian dengan kebutuhan yang telah berkembang dan berlaku di tengah-tengah masyarakat. Diperlukan adanya forum kajian atau musyawarah yang harus dilakukan oleh NU dan Muhammadiyah yang diikuti oleh para ahli hukum Islam dan ahli-ahli perbankan agar kajiannya lebih komprehensif dan hasilnya diharapkan lebih mendekati bahkan sesuai dengan realitas dalam praktik perbankan di Indonesia.

2. Dalam menyikapi perbedaan persepsi tentang bunga bank pada persoalan prosedurnya, disarankan agar prosedur itu dapat disesuaikan dengan keyakinan banyak pihak yang akan menggunakan jasa bank, karena sesuai dengan perundang-undangan yang berlaku saat ini, masih ada kemungkinan untuk diupayakan terwujudnya ketentuan hukum bunga bank yang lebih sempurna bagi masyarakat.

3. Untuk para cendekiawan agar proaktif dan serius menggali sekaligus ikut memecahkan masalah-masalah hukum Islam kontemporer, agar dapat memperkaya khazanah pemikiran dengan tidak membatasi disiplin ilmu, tokoh maupun kelompoknya, sehingga tidak membuka ruang konflik, serta dapat mengembangkan sikap toleran dan saling memahami sehingga sikap mengklaim diri atau kelompoknya yang paling benar dapat terhindarkan.

\section{Referensi}

Abd. Salam Arief. Bank Islam: Suatu Alternatif Pemberdayaan Ekonomi Umat, Jurnal Asy-Syir'ah. Volume 6. Nomor 7. 2000

Abdul Wahab Khallaf. 1968. 'IIm Usul Fiqh. Kairo: Dar al-Kuwaitiyyah.
Abdul Wahid Zaini. 1994. Dunia Pemikiran Kaum Santri. Yogyakarta: LKPSM.

Abu Hamdan Abdu al-Jalil Hamid. T.t.t. Ahkam al-Fuqaha' fi al-Muqarrarat Mu'tamarat Nahdatu al-Ulama'. Juz II. Semarang: Toha Putra.

Abu Umar Faruq dan Muhammad Kabir Hassan. Riba and Islamic Banking. Journal of Islamic Economic, Banking, and Finance. Volume 7. Nomor 2. 2009.

Abu Zahra. 1970. Buhus fi ar-Riba. ttp:Dar alBuhus al-IImiyyah.

Abul Husain Muslim bin al-Hajjaj al-Qusyairi anNaisaburi. T. t. Sahih Muslim. Bandung: al-Ma'arif.

Fathurrahman Djamil. 1995. Metode ljtihad Majlis Tarjih Muhammadiyah. Cetakan I. Jakarta: Logos Publishing House.

Fuad Zein. 2002. Aplikasi Ushul Fiqh Dalam Mengkaji Keuangan Kontemporer, Ainur Rafiq (ed.), Mazhab Jogja: Menggagas Paradigma Ushul Fiqh Kontemporer. Cetakan I. Yogyakarta: Ar-Ruzz.

Heri Sudarsono. 2003. Bank dan Lembaga Keuangan Syari'ah: Deskripsi dan Ilustrasi. Cetakan I. Yogyakarta: Ekonsia.

Ibnu Hajar al-'Asqalani. T.t, Bulugu alMaram.Juz I. Surabaya: al-Hidayah.

M. Quraish Syihab. 2003. Membumikan AlQur'an: Fungsi dan Peran Wahyu dalam Kehidupan Masyarakat. Cetakan XXVI. Bandung: Mizan.

Mohammad Anton Athoillah. Ekonomi Islam: Transaksi dan Problematiknya. ljtihad. Jurnal Wacana Hukum Islam dan Kemanusiaan. Volume 13. Nomor 2. Desember 2013.

Mohammad Anton Athoillah dan Sofyan al Hakim. Reinterpreting The Ratio Legis of Prohibition of Usury. Middle East Journal of Scientific Research. Volume 14. Nomor 10. 2013. 
Muhammad Muflih. Rekonstruksi Pemahaman Terhadap Konsep Riba Pada Transaksi Perbankan Konvensional. Ahkam. Volume XIII. Nomor 1. Januari 2013.

Muhammad Zuhri. 1996. Riba dalam al-Qur'an dan Masalah Perbankan: Sebuah Tilikan Antisipatif. Cetakan I. Jakarta: Raja Grafindo.
Nur Chamid. 2005. Problematika Riba dan Bunga Bank. Jurnal Empirisma. Volume 14. Nomor 2. 2005.

Pimpinan Pusat Muhammadiyah. T.t.t. Himpunan Putusan Majlis Tarjih Muhammadiyah. Yogyakarta: Persatuan.

Soerjono Soekamto. 1990. Pokok-pokok Sosiologi Hukum. Jakarta: Rajawali Press. 